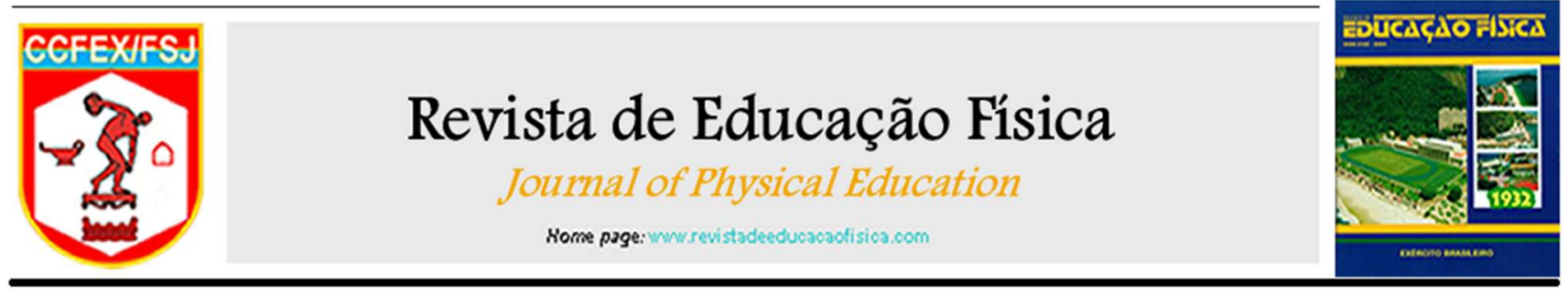

Original Article

Artigo Original

\title{
Psychomotor profile of scholarly children (6 and 10 years old) in Pereira city, Colombia
}

\section{Perfil psicomotor de crianças em idade escolar (entre 6 e 10 anos) da cidade de Pereira, Colômbia}

Pedro Antonio Calero Saa ${ }^{\S 1} \mathrm{PhD}$; Hernán Mauricio Garcia Cardona²; Carlos Alberto Quintero3 ; Jose Armando Vidarte Claros ${ }^{4} \mathrm{PhD}$; Carolina Sandoval Cuellar ${ }^{1}$

Recebido em: 18 de agosto de 2016. Aceito em: 26 de setembro de 2016. Publicado online em: 29 de dezembro de 2016.

\begin{abstract}
Introduction: The psychomotor profile of children is directed related to the psychomotor development, understood as a process of continuous evolution that happens over the years.

Objective: This article attempts to determine the psychomotor profile of children aged between 6 and 10 years, from educational institutions in the city of Pereira, Risaralda (Colombia).

Methods: Through a cross descriptive quantitative study with a comparative phase, 26,448 children were eligible to participate the study, meeting the inclusion criteria. From them, a sample of 420 children aged between 6 and 10 years was selected, obtained from the formula for finite populations, with a prevalence of $44 \%$ of reference; sampling was a simple random. The instrument used was the Vitor da Fonseca's test battery of psychomotor development. Chi-square was used to evaluate association of age, education level and residential

\begin{tabular}{|l|}
\hline Keypoints \\
- The psychomotor development \\
profile of a populational sample \\
of children were evaluated. \\
- Participating schools' \\
neighborhood belong to the \\
lowest socioeconomic strata. \\
-Nevetheless, 90.2\% of the \\
children presented Good \\
psychomotor development. \\
\hline
\end{tabular}
community with level of confidence of $95 \%$.

Results: The sample was composed of 222 girls (52.9\%; CI 47-56) and 198 boys (47\%; CI 42-51). 90.2\% (95\%CI 87-92) presented psychomotor profile classified as Good (Eupraxic) while 4.0\% (95\%CI 3-4) were on Satisfactory (Dyspraxic) range and 5.7\% (95\%CI 4-5) exhibited Excellent (Hyperpraxic) psychomotor profile.

Conclusion: In general, the children evaluated presented adequate psychomotor development. Results according to the factors (Tonicity, Laterality, Body Notion, Balance, Time Space, Global Praxia and Fine Praxia) were discussed.
\end{abstract}

Keywords: psychomotor performance, child, child development.

\footnotetext{
$\S$ Corresponding Author: Pedro Antonio Calero Saa - e-mail: pacalero@uniboyaca.edu.co Affiliations: ${ }^{1}$ Teacher Corps Research Group. University of Boyacá, ${ }^{2}$ Teaching Health Research Group Culture, Technological University of Pereira, ${ }^{3}$ Educational Researcher Group Body and Movement. Autonomous University of Manizales.
} 


\section{Resumo}

Introdução: 0 perfil psicomotor da criança está diretamente relacionado com o desenvolvimento psicomotor, o qual é entendido como um processo de evolução contínua que acontece à medida que os anos passam.

Objetivo: Este artigo buscou determinar o perfil psicomotor de crianças com idade entre 6 e 10 anos, das instituições de ensino dentro da cidade de Pereira, Risaralda (Colômbia).

Métodos: Um estudo descritivo quantitativo foi realizado, com a participação de todas as escolas de Pereira: 26.448 crianças preencheram os critérios de inclusão, sendo, portanto, elegíveis para participar do estudo. Destas, uma amostra de 420 crianças com idades entre 6 e 10 anos foi selecionada pelo método de amostragem aleatória simples para populações finitas, com uma prevalência de $44 \%$ de referência. Para avaliar o desenvolvimento psicomotor foi utilizado a bateria de testes de Vitor da Fonseca. 0 teste Qui-quadrado foi utilizado para avaliar a associação de idade, escolaridade e comunidade residencial com nível de confiança de 95\%.

Resultados: A amostra foi composta por 222 meninas (52,9\%;

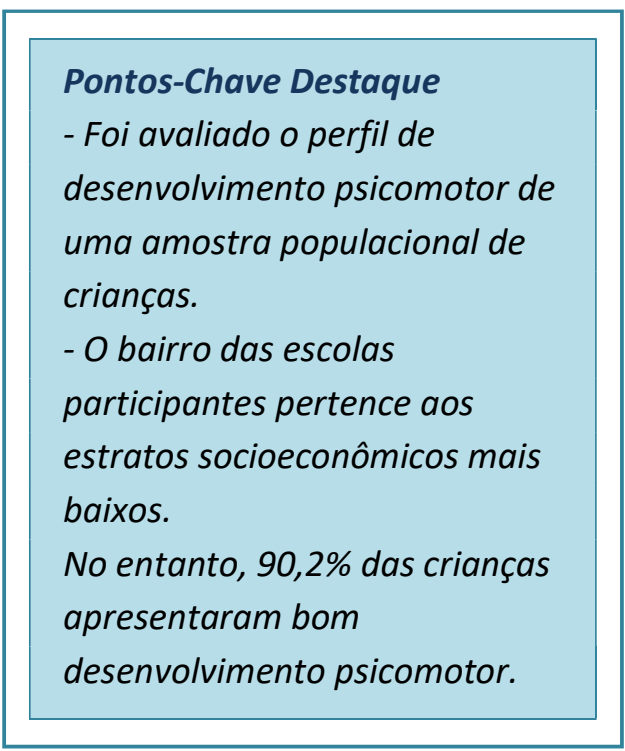

IC 47-56) e 198 meninos (47\%; CI 42-51). 90,2\% (95\% IC 87-92) dos participantes apresentaram perfil de desenvolvimento psicomotor classificado como Bom (Eupráxico); 4,0\% (IC 95\% 3-4) apresentaram perfil Satisfatório (Dispráxico) e 5,7\% (IC95\% 4-5) exibiram perfil de desenvolvimento psicomotor Excelente (Hiperpráxico).

Conclusão: Em geral, as crianças avaliadas apresentaram desenvolvimento psicomotor adequado. Os resultados segundo fatores (Tonicidade, Lateralidade, Noção Corporal, Equilíbrio, Espaço de Tempo, Praxia Global e Praxia Fina) foram discutidos.

Palavras-chave: desempenho psicomotor, criança, desenvolvimento infantil.

\section{Psychomotor profile of scholarly children (6 and 10 years old) in Pereira city, Colombia}

\section{Introduction}

The psychomotor profile in children is directed related to psychomotor development. It is understood as a process of continuous evolution that happens over the years. This process occurs in different stages, each one with specific characteristics, allowing the child to acquire and develop new skills which facilitates their adaptation to the environment and respond assertively and efficiently to a task. Motor development is individual to each child, but should develop the same order in all individuals. For example, the functional development, which occurs at a cephalocaudal level(2). On the other hand, different developmental disorders influence the psychomotor profile in children. Vidarte et al.(3) compared the psychomotor profile in children (5-12 years old) with a clinical diagnosis of attention deficit hyperactivity disorder (ADHD) and healthy children of the same age. They found that psychomotor profile in children with ADHD was qualified together with healthy children as eupraxic. However, their scores and the quality of execution in each factor was lower(3). According to Granda(4), at school age, motor development has a great importance due to the richness of the motor behavior and increased motor control. At this stage, child's growth slows down; this explains why children can improve both their abilities to control their bodies over the years. Children who are at school age can perform any motor activity, if it doesn't require neither great strength nor speed and distance calculation. Naturally, the specific skills that the child masters will depend on the opportunities and challenges that he/she may find(5). Consequently, knowledge development and sequentially in the early years of life allows the establishment of appropriate educational intervention strategies(6). 
The child development during the first three years of life depends exclusively on various factors, such as: the environment in which the child grows; the nutritional components; some aspects related to health; social development and the protection he/she receives, which will be potentiated with better quality of attention, care; and education that allows them to develop at a physical, social, emotional and cognitive aspects in an optimal way(7). Psychomotricity relates biological and cultural determinants in child, which may be provided by the relationship of behavior and child development. The nervous system maturation will allow the formulation of appropriate educational, therapeutic and rehabilitation strategies the most suitable for their needs(8). In this sense, Psychomotor development depends on the experiences that children acquire during childhood, considering that they are characterized by impulses of play and movement, which are strengthened as they "discover the motor possibilities of doing more activities"(9). Noguera et al.(11) correlated the psychomotor profile and the logicalmathematical performance of children aged between 4 and 8 years using the psychomotor development battery proposed by Vitor da Fonseca(8) and concluded found direct correlation of logical-mathematical performance with psychomotor profile of children. Although the correlation was low, it indicates that the engine development contributes to the acquisition of academic skills.

This article aimed to determine the psychomotor profile of children aged between 6 and 10 years, from educational institutions in the city of Pereira, Risaralda (Colombia).

\section{Methods}

\section{Study design and sample}

This research was a cross-sectional quantitative study with a comparative stage. From the scholar children population $(\mathrm{N}=26,448)$ of Pereira, Risaralda (Colombia), a sample of 420 children was obtained through the formula for finite populations with qualitative variables. Simple random sampling was used to build lists of students from schools in Pereira, in 2013, which were provided by the Ministry of Education. Inclusion criteria were children in ages between 6 and 10 years attending in schools in the city of Pereira, in 2013, with no musculoskeletal disorders and have informed consent authorized by parents or guardians. Exclusion criteria were met by children in the process of tracking learning difficulties in each of the institutions. Random numbers were obtained through Excel which identified the children to be evaluated.

The ethical precautions were explained to the teachers both verbally and personally, they were told about the application of the battery psychomotor test and parents and the administration of the institutions were asked to sign the informed consent to carry out the study.

\section{Study variables}

\section{Psychomotor development}

The outcome variable was the psychomotor development evaluated using the psychomotor development battery of Vitor da Fonseca (8), consisting of open and closed questions - that present a set of situations which permits to dynamically analyze the psychomotor profile of children, in attempt to cover the psychoneurological integration in accordance with the functional organization of the brain. This concept was proposed to try to quantify the relationship with its dynamic potential and the probability of learning(8). The instrument was build based on the quality of the psychomotor profile reflecting the degree of neurological organization of the three units (tonic regulation, alertness and mental states; reception, analysis and storage of information; and programming, regulation and verification of activity). The instrument's main purpose is to detect learning difficulties in children. It is a psycho-pedagogical tool that can be used to identify children who do not have the psychomotor skills needed for learning or the underlying skills and rehabilitative strategies(8). As an observational battery, it allows the detection of several components of psychomotor development in a structured and non-stereotyped way. The psychomotor development battery(8) consists of seven factors: Tonicity, Balance, Laterality, Body Notion, Time Space (temporal space structuration), Global Praxia and Fine Praxia. The battery is divided into three sub factors. 
The tasks that make up the BPM give the opportunity enough to identify the degree of psychomotor maturation of the child and to detect deviated signals that help to understand evolutionary discrepancies in situations of infantile and primary school learning. The calculation of the global psychomotor profile is given from the sum of the values of each factor (the major score is 4 and the smallest is $1)$. Thus, the largest sum for the instrument is 28 and the smallest is 7 . The classification of the psychomotor development scores is as follows: 1) From 1 to 7 points: Weak / Apraxic profile (imperfect, incomplete and uncoordinated); 2) From 8 to 14 points Satisfactory / Dyspraxic profile (achievement - dealing with the control difficulties); 3) From 15 to 21 points: Good / Eupraxic profile (controlled and adequate); 4) From 22 to 28 points: Excellent / Hyperpraxic profile (perfect, controlled, harmonious and well controlled.

\section{Sociodemographic characteristics}

The study had the sociodemographic variables gender, categorized by male or female; the schooling variable, categorized by first, second, third, fourth and fifth grade; and communities were: Boston, Universidad, Centro and Jardin.

\section{Statistical Analysis}

Systematization of information was conducted in SPSS version $20 \AA$ program with respective cleaning and data cleaning. The first stage of the univariate analysis of categorical variables and their magnitude was subsequently carried out, through the distribution of absolute and relative frequencies. Measures of central tendency and variability or dispersion for quantitative variables were also calculated. The development of bivariate analysis sought to establish any possible relationship of psychomotor development and sociodemographic variables. To determine the statistical significance of the dependency of the sociodemographic characteristics with the psychomotor factors, Chi Square test was applied. Additionally, the numerical variables relationships were established through the application of Pearson and Spearman tests. The significance level for all analyses was of $95 \%$.

\section{Results}

After the sampling process, 420 children (aged 6-10 years old) took part in the study. $52.9 \%$ were females and mean of age was 8.68 years, with a greater proportion of children aged 10 years old (38.1\%), corresponding to the fifth grade in schooling level. Table 1 exhibits the distribution of sociodemographic characteristics. Regarding place of residence, Boston commune had a higher frequency of children (32.1\%).

The psychomotor development evaluated by factors in the study population and distribution according to sociodemographic characteristics is presented in Table 1. Regarding the assessment of Tonicity, the highest percentage of individuals that scored Excellent (68.4\%) was the age category of 9 to 10 years old. Regarding gender, the majority of male $(60.6 \%)$ achieved the Excellent score. For schooling, children at the fifth grade presented the highest frequency of individuals with score Excellent. For place of residence, the highest frequency of individuals with excellent Tonicity ratings reported to live in the Boston Community.

Table 1 - Distribution of sociodemographic characteristics

\begin{tabular}{lccc}
\hline Gender & Frequency & $\mathbf{\%}$ & $\begin{array}{c}\text { IC } \\
\mathbf{9 5 \%}\end{array}$ \\
Male & 198 & 47.1 & $42-51$ \\
Female & 222 & 52.9 & $47-56$ \\
Schooling & & & \\
$\quad$ First & 52 & 12.4 & $8-15$ \\
Second & 45 & 10.7 & $7-12$ \\
Third & 62 & 14.8 & $10-17$ \\
Fourth & 121 & 28.8 & $23-32$ \\
$\quad$ Fifth & 140 & 33.3 & $28-37$ \\
Community & & & \\
Boston & 135 & 32.1 & $27-36$ \\
Universidad & 92 & 21.9 & $17-24$ \\
$\quad$ Centro & 96 & 22.9 & $18-25$ \\
$\quad$ Jardín & 97 & 23.1 & $18-27$ \\
\hline
\end{tabular}

By establishing dependencies between Tonicity assessment and sociodemographic characteristics, age, community and schooling were associated with psychomotor development $(\mathrm{p}<0.05) \quad($ Table 2$)$. Regarding the Balance assessment, children between 9 and 10 years and fifth-grade children living in the Boston community old obtained score Excellent. 
Table 2 - Psychomotor development according to sociodemographic characteristics

\begin{tabular}{|c|c|c|c|c|c|c|c|c|}
\hline Factor / Characteristic & Weak & Satisf. & Good & Excellent & $\mathbf{X}^{2}$ & $P^{a}$ & Phi & $P^{b}$ \\
\hline \multicolumn{9}{|l|}{ Tonicity } \\
\hline Age & & & & & 27.073 & 0.000 & 0.254 & 0.000 \\
\hline 6-8 Years & $0.0 \%$ & $1.3 \%$ & $56.3 \%$ & $42.4 \%$ & & & & \\
\hline 9-10 Years & $0.0 \%$ & $0.7 \%$ & $30.9 \%$ & $68.4 \%$ & & & & \\
\hline Sex & & & & & 0.412 & 0.814 & 0.031 & 0.814 \\
\hline Male & $0.0 \%$ & $1.0 \%$ & $38.4 \%$ & $60.6 \%$ & & & & \\
\hline Female & $0.0 \%$ & $0.9 \%$ & $41.4 \%$ & $57.7 \%$ & & & & \\
\hline Schooling & & & & & 42.990 & 0.000 & 0.320 & 0.000 \\
\hline First & $0.0 \%$ & $0.0 \%$ & $57.7 \%$ & $42.3 \%$ & & & & \\
\hline Second & $0.0 \%$ & $4.4 \%$ & $57.8 \%$ & $37.8 \%$ & & & & \\
\hline Third & $0.0 \%$ & $1.6 \%$ & $53.2 \%$ & $11.3 \%$ & & & & \\
\hline Fourth & $0.0 \%$ & $0.8 \%$ & $38.0 \%$ & $61.2 \%$ & & & & \\
\hline Fifth & $0.0 \%$ & $0.0 \%$ & $23.6 \%$ & $76.4 \%$ & & & & \\
\hline Community & & & & & 33.682 & 0.000 & 0.283 & 0.000 \\
\hline Boston & $0.0 \%$ & $0.7 \%$ & $47.4 \%$ & $51.9 \%$ & & & & \\
\hline Universidad & $0.0 \%$ & $0.0 \%$ & $18.5 \%$ & $81.5 \%$ & & & & \\
\hline Centro & $0.0 \%$ & $0.0 \%$ & $52.1 \%$ & $47.9 \%$ & & & & \\
\hline Jardín & $0.0 \%$ & $3.1 \%$ & $38.1 \%$ & $58.8 \%$ & & & & \\
\hline \multicolumn{9}{|l|}{ Balance } \\
\hline Age & & & & & 32.982 & 0.000 & 0.280 & 0.000 \\
\hline 6-8 Years & $0.7 \%$ & $7.3 \%$ & $63.6 \%$ & $28.5 \%$ & & & & \\
\hline 9-10 Years & $0.0 \%$ & $3.3 \%$ & $39.8 \%$ & $56.9 \%$ & & & & \\
\hline Sex & & & & & 8.464 & 0.037 & 0.142 & 0.037 \\
\hline Male & $0.0 \%$ & $2.0 \%$ & $47.0 \%$ & $51.0 \%$ & & & & \\
\hline Female & $0.5 \%$ & $7.2 \%$ & $49.5 \%$ & $42.8 \%$ & & & & \\
\hline Schooling & & & & & 58.481 & 0.000 & 0.373 & 0.000 \\
\hline First & $1.9 \%$ & $15.4 \%$ & $65.4 \%$ & $17.3 \%$ & & & & \\
\hline Second & $0.0 \%$ & $2.2 \%$ & $68.9 \%$ & $28.0 \%$ & & & & \\
\hline Third & $0.0 \%$ & $3.2 \%$ & $61.3 \%$ & $35.5 \%$ & & & & \\
\hline Fourth & $0.0 \%$ & $3.3 \%$ & $35.5 \%$ & $61.2 \%$ & & & & \\
\hline Fifth & $0.0 \%$ & $3.6 \%$ & $40.7 \%$ & $55.7 \%$ & & & & \\
\hline
\end{tabular}


Rev Ed Física / J Phys Ed - Psychomotor profile of scholarly children in Pereira 392

\begin{tabular}{|c|c|c|c|c|c|c|c|c|}
\hline Factor / Characteristic & Weak & Satisf. & Good & Excellent & $\mathbf{X}^{2}$ & $P^{a}$ & Phi & $P^{b}$ \\
\hline Community & & & & & 24.355 & 0.004 & 0.241 & 0.004 \\
\hline Boston & $0.0 \%$ & $3.0 \%$ & $39.3 \%$ & $57.8 \%$ & & & & \\
\hline Universidad & $1.1 \%$ & $8.7 \%$ & $41.3 \%$ & $48.9 \%$ & & & & \\
\hline Centro & $0.0 \%$ & $5.2 \%$ & $52.1 \%$ & $42.7 \%$ & & & & \\
\hline Jardín & $0.0 \%$ & $3.1 \%$ & $63.9 \%$ & $33.0 \%$ & & & & \\
\hline \multicolumn{9}{|l|}{ Laterality } \\
\hline$\overline{A g e}$ & & & & & 5.244 & 0.022 & 0.111 & 0.022 \\
\hline 6-8 Years & $0.0 \%$ & $0.0 \%$ & $66.2 \%$ & $33.8 \%$ & & & & \\
\hline 9-10 Years & $0.0 \%$ & $0.0 \%$ & $76.6 \%$ & $23.4 \%$ & & & & \\
\hline $\operatorname{Sex}$ & & & & & 0.677 & 0.411 & 0.040 & 0.411 \\
\hline Male & $0.0 \%$ & $0.0 \%$ & $74.7 \%$ & $25.3 \%$ & & & & \\
\hline Female & $0.0 \%$ & $0.0 \%$ & $71.2 \%$ & $28.8 \%$ & & & & \\
\hline Schooling & & & & & 9.030 & 0.060 & 0.145 & 0.060 \\
\hline First & $0.0 \%$ & $0.0 \%$ & $71.2 \%$ & $28.8 \%$ & & & & \\
\hline Second & $0.0 \%$ & $0.0 \%$ & $57.8 \%$ & $42.2 \%$ & & & & \\
\hline Third & $0.0 \%$ & $0.0 \%$ & $71.0 \%$ & $29.0 \%$ & & & & \\
\hline Fourth & $0.0 \%$ & $0.0 \%$ & $71.9 \%$ & $28.1 \%$ & & & & \\
\hline Fifth & $0.0 \%$ & $0.0 \%$ & $80.0 \%$ & $20.0 \%$ & & & & \\
\hline Community & & & & & 123.789 & 0.000 & 0.477 & 0.000 \\
\hline Boston & $0.0 \%$ & $0.0 \%$ & $88.1 \%$ & $11.9 \%$ & & & & \\
\hline Universidad & $0.0 \%$ & $0.0 \%$ & $73.9 \%$ & $26.1 \%$ & & & & \\
\hline Centro & $0.0 \%$ & $0.0 \%$ & $30.2 \%$ & $69.8 \%$ & & & & \\
\hline Jardín & $0.0 \%$ & $0.0 \%$ & $92.8 \%$ & $7.2 \%$ & & & & \\
\hline \multicolumn{9}{|l|}{ Body Notion } \\
\hline$\overline{\text { Age }}$ & & & & & 41.40 & 0.000 & 0.314 & 0.000 \\
\hline 6-8 Years & $1.3 \%$ & $55.0 \%$ & $42.4 \%$ & $1.3 \%$ & & & & \\
\hline 9-10 Years & $0.7 \%$ & $24.2 \%$ & $72.1 \%$ & $3.0 \%$ & & & & \\
\hline Sex & & & & & 2.155 & 0.541 & 0.07 & 0.541 \\
\hline Male & $1.5 \%$ & $35.9 \%$ & $59.6 \%$ & $3.0 \%$ & & & & \\
\hline Female & $0.5 \%$ & $34.7 \%$ & $63.1 \%$ & $1.8 \%$ & & & & \\
\hline Schooling & & & & & 48.357 & 0.000 & 0.339 & 0.000 \\
\hline First & $0.0 \%$ & $55.8 \%$ & $40.4 \%$ & $3.8 \%$ & & & & \\
\hline Second & $0.0 \%$ & $57.8 \%$ & $42.2 \%$ & $0.0 \%$ & & & & \\
\hline Third & $3.2 \%$ & $50.0 \%$ & $45.2 \%$ & $1.6 \%$ & & & & \\
\hline Fourth & $0.8 \%$ & $27.3 \%$ & $69.4 \%$ & $2.5 \%$ & & & & \\
\hline Fifth & $0.7 \%$ & $20.7 \%$ & $75.7 \%$ & $2.9 \%$ & & & & \\
\hline
\end{tabular}


Rev Ed Física / J Phys Ed - Psychomotor profile of scholarly children in Pereira 393

\begin{tabular}{|c|c|c|c|c|c|c|c|c|}
\hline Factor / Characteristic & Weak & Satisf. & Good & Excellent & $\mathbf{X}^{2}$ & $P^{a}$ & Phi & $P^{b}$ \\
\hline Community & & & & & 45.116 & 0.000 & 0.328 & 0.000 \\
\hline Boston & $0.0 \%$ & $39.3 \%$ & $60 \%$ & $0.7 \%$ & & & & \\
\hline Universidad & $0.0 \%$ & $16.3 \%$ & $77.2 \%$ & $6.5 \%$ & & & & \\
\hline Centro & $4.2 \%$ & $47.9 \%$ & $47.9 \%$ & $0.0 \%$ & & & & \\
\hline Jardín & $0.0 \%$ & $35.0 \%$ & $61.9 \%$ & $3.1 \%$ & & & & \\
\hline \multicolumn{9}{|l|}{ Time Space } \\
\hline \multicolumn{9}{|l|}{$\overline{A g e}$} \\
\hline 6-8 Years & $5.3 \%$ & $41.1 \%$ & $51 \%$ & $2.6 \%$ & 66.280 & 0.000 & 0.397 & 0.000 \\
\hline 9-10 Years & $0.0 \%$ & $12.3 \%$ & $78.8 \%$ & $8.9 \%$ & & & & \\
\hline \multicolumn{9}{|l|}{$\operatorname{Sex}$} \\
\hline Male & $2.0 \%$ & $26.3 \%$ & $62.6 \%$ & $9.1 \%$ & 7.608 & 0.055 & 0.135 & 0.000 \\
\hline Female & $1.8 \%$ & $19.4 \%$ & $74.3 \%$ & $4.5 \%$ & & & & \\
\hline \multicolumn{9}{|l|}{ Schooling } \\
\hline First & $9.6 \%$ & $46.2 \%$ & $40.4 \%$ & $3.8 \%$ & 86.533 & 0.000 & 0.454 & 0.000 \\
\hline Second & $2.2 \%$ & $42.2 \%$ & $55.6 \%$ & $0.0 \%$ & & & & \\
\hline Third & $3.2 \%$ & $35.5 \%$ & $58.1 \%$ & $3.2 \%$ & & & & \\
\hline Fourth & $0.0 \%$ & $18.2 \%$ & $73.6 \%$ & $8.3 \%$ & & & & \\
\hline Fifth & $0.0 \%$ & $5.7 \%$ & $84.3 \%$ & $10.0 \%$ & & & & \\
\hline Community & & & & & 63.218 & 0.000 & 0.388 & 0.000 \\
\hline Boston & $0.7 \%$ & $20.7 \%$ & $73.3 \%$ & $5.2 \%$ & & & & \\
\hline Universidad & $0.0 \%$ & $7.6 \%$ & $71.7 \%$ & $20.7 \%$ & & & & \\
\hline Centro & $2.1 \%$ & $28.1 \%$ & $69.8 \%$ & $0.0 \%$ & & & & \\
\hline Jardín & $5.1 \%$ & $34.0 \%$ & $58.9 \%$ & $20.1 \%$ & & & & \\
\hline \multicolumn{9}{|l|}{ Global Praxia } \\
\hline$\overline{\text { Age }}$ & & & & & 30.098 & 0.000 & 0.268 & 0.000 \\
\hline $6-8$ Years & $1.3 \%$ & $54.3 \%$ & $43.7 \%$ & $0.7 \%$ & & & & \\
\hline 9-10 Years & $0.7 \%$ & $28.6 \%$ & $66.2 \%$ & $4.5 \%$ & & & & \\
\hline Sex & & & & & 6.726 & 0.081 & 0.127 & 0.081 \\
\hline Male & $1 \%$ & $43.9 \%$ & $53.0 \%$ & $2.0 \%$ & & & & \\
\hline Female & $0.9 \%$ & $32.4 \%$ & $62.6 \%$ & $4.1 \%$ & & & & \\
\hline Schooling & & & & & 43.617 & 0.000 & 0.322 & 0.000 \\
\hline First & $0.0 \%$ & $55.8 \%$ & $42.3 \%$ & $1.9 \%$ & & & & \\
\hline Second & $0.0 \%$ & $66.7 \%$ & $33.3 \%$ & $0.0 \%$ & & & & \\
\hline Third & $3.2 \%$ & $45.2 \%$ & $51.6 \%$ & $0.0 \%$ & & & & \\
\hline Fourth & $0.8 \%$ & $26.4 \%$ & $68.6 \%$ & $4.1 \%$ & & & & \\
\hline Fifth & $0.7 \%$ & $28.6 \%$ & $65.7 \%$ & $5.0 \%$ & & & & \\
\hline
\end{tabular}


Rev Ed Física / J Phys Ed - Psychomotor profile of scholarly children in Pereira 394

\begin{tabular}{|c|c|c|c|c|c|c|c|c|}
\hline Factor / Characteristic & Weak & Satisf. & Good & Excellent & $\mathbf{X}^{2}$ & $P^{a}$ & Phi & $P^{b}$ \\
\hline Community & & & & & 10.779 & 0.291 & 0.160 & 0.291 \\
\hline Boston & $1.5 \%$ & $41.5 \%$ & $51.9 \%$ & $5.2 \%$ & & & & \\
\hline Universidad & $0.0 \%$ & $37.0 \%$ & $58.7 \%$ & $4.3 \%$ & & & & \\
\hline Centro & $2.1 \%$ & $34.4 \%$ & $62.5 \%$ & $1.0 \%$ & & & & \\
\hline Jardín & $0.0 \%$ & $37.1 \%$ & $61.9 \%$ & $1.0 \%$ & & & & \\
\hline \multicolumn{9}{|l|}{ Fine Praxia } \\
\hline Age & & & & & 111.157 & 0.000 & 0.514 & 0.000 \\
\hline 6-8 Years & $2.0 \%$ & $23.2 \%$ & $64.9 \%$ & $9.9 \%$ & & & & \\
\hline 9-10 Years & $0.0 \%$ & $1.9 \%$ & $43.1 \%$ & $55 \%$ & & & & \\
\hline Sex & & & & & 8.489 & 0.037 & 0.142 & 0.037 \\
\hline Male & $0.5 \%$ & $7.6 \%$ & $46.0 \%$ & $46.0 \%$ & & & & \\
\hline Female & $0.9 \%$ & $11.3 \%$ & $55.4 \%$ & $32.4 \%$ & & & & \\
\hline Schooling & & & & & 153.083 & 0.000 & 0.604 & 0.000 \\
\hline First & $1.9 \%$ & $40.4 \%$ & $55.8 \%$ & $1.9 \%$ & & & & \\
\hline Second & $4.4 \%$ & $20.0 \%$ & $73.3 \%$ & $2.2 \%$ & & & & \\
\hline Third & $0.0 \%$ & $8.1 \%$ & $66.1 \%$ & $25.8 \%$ & & & & \\
\hline Fourth & $0.0 \%$ & $1.7 \%$ & $46.3 \%$ & $52.1 \%$ & & & & \\
\hline Fifth & $0.0 \%$ & $2.1 \%$ & $39.3 \%$ & $58.6 \%$ & & & & \\
\hline Community & & & & & 20.366 & 0.016 & 0.220 & 0.016 \\
\hline Boston & $0.7 \%$ & $6.7 \%$ & $48.1 \%$ & $44.4 \%$ & & & & \\
\hline Universidad & $1.1 \%$ & $9.8 \%$ & $38.0 \%$ & $51.1 \%$ & & & & \\
\hline Centro & $0.0 \%$ & $8.3 \%$ & $62.5 \%$ & $29.2 \%$ & & & & \\
\hline Jardín & $1.0 \%$ & $14.4 \%$ & $55.7 \%$ & $28.9 \%$ & & & & \\
\hline
\end{tabular}

Satisf.: Satisfactory;

${ }^{\text {a }} \boldsymbol{P}: \mathrm{p}$-value results from correlation analyses of Pearson / Spearman

${ }^{\mathrm{b}} \boldsymbol{P}$ : $\mathrm{p}$-value results from $\mathrm{Chi}$ squared test. 
There was dependency between Laterality and age, schooling and community $(\mathrm{p}<0.05)$. For the evaluation of Laterality and the Body Notion, children in the age category between 9 and 10 years old presented the psychomotor development rated as good they were from fifth-grade and in the Garden community. A statistically significant dependency was observed between the Laterality factor and age $(p=0.022)$. In relation to the Body Notion, age, education level and community were associated to the psychomotor development $(\mathrm{p}=0.000)$.

In relation to Time Space and Global Praxia factors, the majority $(78.8 \%)$ of the children between 9 and 10 years old evidenced score Good There were statistically significant dependency between the Time Space factor and age, education level and community $(p<0.05)$. Likewise, age and schooling were associated with Global Praxia $(\mathrm{p}<0.05)$. The Fine Praxia evaluation showed a higher percentage of individuals between 9 and 10 years old with a grade of good with $43.1 \%$, in relation to gender, girls excel with $55.4 \%$ with the rating of Bueno. According to the degree of schooling, the highest frequency was the fifthgrade individuals and according to the Commune of residence, the highest frequency was obtained from individuals with a score of Good of the Boston Commune. The dependency obtained between the Global Praxia factor and the sociodemographic characteristics exhibited a statistically significant dependency of age, education level and community with psychomotor development $(\mathrm{p}=0.000)$ (Table 2$)$.

It is reported that in the final Psychomotor profile (see Table 3), a higher frequency for the eupraxic profile evidenced with a $90.2 \%$.

Table 1 - Distribution of sociodemographic characteristics

\begin{tabular}{lrrc}
\hline \multicolumn{1}{c}{ Profile } & Freq. & \% & IC 95\% \\
\hline \hline Dyspraxic (Satisfactory) & 17 & 4.0 & $3-4$ \\
Eupraxic (Good) & 379 & 90.2 & $87-92$ \\
Hyperpraxic (Excellent) & 24 & 5.7 & $4-5$ \\
Total & 420 & 100.0 & \\
\hline
\end{tabular}

\section{Discussion}

The main results of the present study were that sociodemographic characteristics were associated with psychomotor development. All participating educational institutions were public entities and were in neighborhoods classified in the 2nd and 3rd strata (Colombian system of classification of economic status, which ranges from 1st being the lowest and 6th the highest). Some studies showed that social status, malnutrition and family relationships are risk factors for neuropsychomotor developmental delay(13-14). Other studies suggest that sociocultural factors have a negative impact on the psychomotor development of children(15). In this context, our results are in line with literature. Among the most relevant results it is Tonicity psychomotor factor, in which the majority of the participants (59\%) scored Excellent. Da Fonseca(16) says that "tonicity is contained in all manifestations of mobility (...) any study of human movement, and particularly on motor skills, must not overlook tonicity, as an essential support factor without which, that form of expression cannot be achieved". In respect to the relationship of age, it is noted that $49.4 \%$ of the children in the range of $9-10$ years old and $50.6 \%$ in the range of $6-8$ years presented score Good for Tonicity evaluation, a very similar percentage, which differs from some studies where it was found a tendency to improve execution over the years(3).

For Balance, which examined static and dynamic aptitudes covering postural control skills and development of locomotion acquisitions(8), study population presented score Good in development of Balance. Concerning the relationship of the factor with the age range, it is noted that the range of 9-10 years had a representation of $78.1 \%$ with a score of Excellent, while the range of 6-8 years old had a greater representation under the score Good with $47.3 \%$. These results differ from the study of Bolivar and Arias (17), in which the Balance factor related to age, had an almost homogeneous behavior between these two age groups. Our findings highlight that "Balance is an essential step in the psycho-neurological development of the child, therefore, it is a key step for all coordinated and purposeful actions, which basically are the support of human learning processes (...)"(8). Conversely, regarding Laterality, only $27.4 \%$ of the study population presented score Excellent. On the other hand, there are some 
issues when the studied population presents a defined lateral dominance(19).

Related to the Body Notion - the basis for the initiation of any intentional movement(8), $61.42 \%$ of the study population scored Good. This finding shows that it would be important to emphasize the development of this factor in those children. Da Fonseca(16) explains that "the notion or image of the body is structured from the peripheral stimuli and references of body movement, resulting in translation and analysis processes of tactile and kinesthetic information, whose final product is the synthesis in the storage of body postures, movement patterns, objective and environmental direction".

For Time Space factor relates to the spatialtemporal location and emerges from the motor skills, and the relationship of the body's position in relation to the objects located in space. Background research from Espejo Vergara and Salas Pérez(20) showed that the spatial-temporal structure is one of the factors that scholarly children show more difficulties. Our results showed that most of the population $(68,8 \%)$ presented score Good. Moreover, there were scores Satisfactory in $22.61 \%$ and score Weak in $1.9 \%$; which, despite being low percentages, they become a group of vital importance for the study leading to generation of psychomotor intervention processes regarding specific learning disorders, since it is precisely these children who find difficulty following normal school rhythm(21). They become then a concern for teachers for being precisely the group of children who fail to advance along the curriculum processes and school activities at the same level as the rest of the group(22).

Furthermore, among the most relevant results of this study, it was found that for the Global Praxia factor, most of the population $(58 \%)$ showed score Good. Jimenez(23) posited that it is important that children develop the mature pattern of different basic patterns, for a better cognitive development. Related to gender, $62.6 \%$ of the females showed score Good, over $53 \%$ of the males. These results differ completely from the findings of Bolivar Gutiérrez et al (17), as for gender, males showed higher levels of psychomotor development in Global Praxia in contrast to women. Another study highlighted that "gross motor skills would be learnt before and they would be executed with a greater efficacy in young boys"(24).

Finally, related to the Fine Praxia, 51\% scored Good and 38.8\% scored Excellent in accordance with Carmona and Arevalo(25), Fine Praxia is one of the factors of psychomotor development which presents major difficulties for children, with a shortterm impact on a difficulty in academic performance and a long-term impact on job performance. In relation to Global and Fine Praxia, Campo (26) found difficulties in fine motor skills and states that deficiencies in the control and coordination of fine muscles of arms and hands alter the participation in specific situations, such as assembling, drawing and writing. Another study found that, in the evaluation of children, the condition of the engine behavior is suitable; although there were difficulties in some areas, those are not significant in their motor development. However, there is a need to intervene in areas where specific problems arose(1). By contrast, another study showed that the psychomotor factors most affected were Fine Praxia and Global Praxia, which involves children's difficulties in carrying out various activities (27). Consequently, among the educational strategies, it is important to recommend the implementation of physical activity programs, which should focus on improving the areas where there is greater difficulty and contribute to the successful engine development of the children.

\section{Strong points and limitations of the study}

A strong point is that the sample was populational representative of all children from public scholar institutions in Pereira.

One of the limitations is the inference of the results on the overall scholar population, which requires a study that includes private scholars as well.

Another issue is that sectional studies presents limits on establishing the cause-effect relationship. Additionally, there are some weak points related to the type of evaluation, as Barbosa et al.(18) described: "the results obtained with the application of these motor tests show specific deficiencies in the acquisition of motor skills of these children". 


\section{Conclusion}

Monitoring children's development is a strategy for preventive intervention that includes activities related to promotion of normal development and troubleshooting development activities. This complies with our goal of to determine the psychomotor profile of children aged between 6 and 10 years from educational institutions within the city of Pereira (Colombia); strengthening the shortage range of existing studies carried on the issue. The benefit of these results will continue to live on in educational environment, where teachers can strengthen the intervention of strategic planning for the different characteristics of students.

Finally, regular application of tests to observe growth and development is recommended, because it is vital to observe whether children are or are not carrying out all the processes of integration and neural response capabilities.

\section{Acknowledgments}

To God, our families, the Autonomous University of Manizales and the University of Boyacá for their support.

\section{Conflict of interests}

There is no conflict of interest in this study.

\section{Funding statement}

Universidad Autónoma de Manizales.

\section{References}

1. Pulgarín J, Hoyos C, Salgado J. Determinación de la praxia fina de los niños de 4 a 14 años pertenecientes a las escuelas de la ciudad de Pereira. [Trabajo de grado]. Pereira: Universidad Tecnológica de Pereira; 2012.

2. Hincapié L, Álvarez A. Evaluación psicomotor del factor del equilibrio en niños pertenecientes a las escuelas de la ciudad de Pereira con edades entre 4 a 14 años basados en la batería de Vítor Da Fonseca. [Trabajo de grado]. Pereira: Universidad Tecnológica de Pereira; 2013.

3. Vidarte J, Ezquerro M, Giraldez M. Perfil psicomotor de niños de 5 a 12 años diagnosticados clínicamente de trastorno por déficit de atención/hiperactividad en
Colombia. REV NEUROL.
2009;49(2):69-75.

4. Granda J, Inmaculada A. Manual de Aprendizaje y desarrollo motor: una perspectiva educativa. Barcelona: Paidós; 2002.

5. Gallardo PV, Camacho JM. Teoría del aprendizaje y educación. España: Departamento de Teoría e Historia de la Educación y Pedagogía Social Sevilla; 2004. p. 85.

6. Campo L. Importancia del desarrollo motor en relación con los procesos evolutivos del lenguaje y la cognición en niños de 3 a 7 años de la ciudad de Barranquilla (Colombia). Salud Uninorte. 2010;26(1):65-76.

7. Gallardo P. El desarrollo emocional en la educación primaria (6-12años). Cuestiones Pedagógicas. 2006-2007;18:143-159.

8. Da Fonseca V. Manual de observación psicomotriz. Primera reseña. Madrid: INDE Publicaciones; 1998.

9. Weineck J. Entrenamiento total. Barcelona: Paidotribo; 2006.

10. Lejarraga H, Krupitzky S, Giménez E, Diament N, Kelmansky D, Tibaldi F. The organization of a national survey for evaluating child psychomotor development in Argentina. Paediatr Perinat Epidemiol. 1997:11;359-73.

11. Noguera L, Herazo Y, Vidarte J. Correlation between psychomotor profile and logical mathematical performance in children 4 to 8 years. Rev Cienc Salud. 2013;11(2):185-194.

12. Barros K, Fragoso A, Oliveira A. Influências do ambiente podem alterar a aquisição de habilidades motoras? Uma comparação entre pré-escolares de creches públicas e escolas privadas. Arq Neuropsiquiatr. 2003;6(2a):170-5.

13. Cabra C, Hincapié S, Jiménez D, Tobón $M$. Estudio descriptivo de los efectos que ejerce el perro como mascota en el desarrollo de la motricidad gruesa de infantes sanos de cinco años de edad. Rev LaSallista Investig. 2011;8(1):82-9. 
14. Sonnander K. Early identification of children with developmental disabilities. Acta Paediatr Suppl. 2000;89:17-23.

15. Bee H. A criança em desenvolvimento. 9 ed. Porto Alegre: Artmed; 2003.

16. Da Fonseca V. Manual de observación psicomotriz. 5 ed. Barcelona: INDE; 2005.

17. Bolívar Gutiérrez PL, Arias Padilla I, Vidarte Claros JA. Perfil psicomotriz de los niños en edades de 8-12 años de las escuelas de formación deportivas del instituto municipal de deporte y la recreación de Armenia (IMDERA). [Tesis de grado]. Manizales: Universidad Autónoma de Manizales; 2012.

18. Barbosa W, Gómez C, Valencia J. Perfil motriz de los niños y niñas de 4 a 6 años del jardín social perlitas del Otún del barrio Tokio, comuna Villa Santana, Pereira, Colombia 2012. [Trabajo de grado]. Pereira: Universidad Tecnológica de Pereira; 2012.

19. Da Silva J, Pereira S, Cassia C, Munis K. Avaliação de funções psicomotoras de crianças entre 6 e 10 anos de idade. Acta Paul Enfermagem. 2005:18(4);403-12.

20. Espejo Vergara L, Salas Pérez JA. Correlación entre el desarrollo psicomotor y el rendimiento escolar, en niños de primer año de educación básica, pertenecientes a establecimientos municipales de dos comunas urbanas de la Región Metropolitana. [Trabajo de grado]. Santiago de Chile: Universidad de Chile; 2004.

21. Bravo Valdivieso L. Psicología de las dificultades del aprendizaje escolar. $7^{\mathrm{a}} \mathrm{ed}$. Santiago de Chile: Universitaria; 1990.

22. Isaza L. Hacia una contextualización de las dificultades en el aprendizaje de la lectura y la escritura. Rev Edu Ped. 2001;13(31):113-133.

23. Jiménez D, Araya V. Más minutos de educación física en preescolares favorecen el desarrollo motor. Revista de Ciencias del Ejercicio y la Salud. 2010;8(1): 1-8.

24. Rosa J, Rodríguez L, Márquez S. Evaluación de la ejecución motora en la edad escolar mediante los tests motores de Lincoln-Oseretsky. Revista Human Movement. 1996;2:129-147.

25. Carmona Y, Arévalo J.T. Conductas motrices de los niños de las principales escuelas del corregimiento de la Florida. [Trabajo de grado]. Pereira: Universidad Tecnológica de Pereira; 2010.

26. Campo TL. Una mirada a los niños y niñas de Barranquilla y su desarrollo evolutivo. Psicogente. 2011;14(26):372-88.

27. Noguera L, Herazo Y, Vidarte J. Correlación entre perfil psicomotor y rendimiento lógico-matemático en niños de 4 a 8 años. Rev Cienc Salud. 2013;11(2);185-194. 